\title{
EFFECT OF ACTIVE AND PASSIVE HEATING METHODS USED IN DIFFERENT AREAS OF PERIOPERATIVE PROCESSES ON THERMAL COMFORT AND ANXIETY: A RANDOMIZED CONTROL TRIAL
}

\author{
Pinar Tunc Tuna', Serife Kursun², Inci Kara ${ }^{3}$ \\ ${ }^{1}$ Sulcuk University, Aksehir Kadir Yallogoz School of Health Sciences, Konya, Turkey \\ 2 Selcuk University, Faculty of Nursing, Konya, Turkey \\ ${ }^{3}$ Selcuk University, Faculty of Medicine, Konya, Turkey \\ Corresponding Author: Pinar Tunc Tuna, PhD, E-mail: pinartunctuna@gmail.com \\ Received: 10.06.2021; Accepted: 05.01.2022; Available Online Date: 27.01.2022 \\ (C) Copyright 2021 by Dokuz Eylül University, Institute of Health Sciences - Available online at https://dergipark.org.tr/en/pub/jbachs
}

Cite this article as: Tunc-Tuna P, Kursun S, Kara I. Effect of Active and Passive Heating Methods Used in Different Areas of Perioperative Processes on Thermal Comfort and Anxiety: A Randomized Control Trial. J Basic Clin Health Sci 2022; 6: $225-237$.

\begin{abstract}
Purpose: This study was aim to determine the effects of active and passive heating methods applied in different parts of the perioperative process on thermal comfort, anxiety, and vital signs.

Design: This study is a randomized, pretest-posttest controlled experimental design. The study was conducted with patients admitted for open abdominal surgery between October 1, 2018 and January 10, 2019.

Methods: Patients were randomly allocated into three groups as follows: Group A $(n=33)$, Group B $(n=33)$, and Group C (control group; $n=33$ ). Intervention Group A and B gowns blowing warm air were used as intervention tools. Active heating was applied to the intervention group. Procedural care (Group C) received routine hospital care. Passive heating was applied to the procedural group. Vital signs, thermal comfort, and anxiety levels of the patients were evaluated.

Results: Compared to those in Group B, for patients in Group A, the thermal comfort levels were higher and the anxiety levels were lower. The highest body temperature was seen in the patients in Group A. No difference was noted in blood pressure values between the groups. The pulse values of the patients in Groups A and B were significantly lower.

Conclusion: The use of gowns blowing warm air had a positive effect on the patients' anxiety, thermal comfort, and vital signs. In future studies, we suggest investigating vital signs and anxiety for different heating techniques and different sample groups.
\end{abstract}

Keywords: Active heating, anxiety, blowing warm air, perioperative nursing, hypothermia, thermal comfort

\section{INTRODUCTION}

Perioperative hypothermia leads to many problems such as surgical site infection (1-3), delay in recovery (4), increased bleeding and blood transfusion frequency (5), pressure wound (6-10), increased oxygen need (11), prolonged hospital stay (2), decreased patient satisfaction (12), increased costs (2), and increased morbidity and mortality (13). In addition to these problems, hypothermia leads to 
deterioration in thermal comfort $(12,14-16)$ an increased level of anxiety $(12,15)$.

Understanding hypothermia and the complications associated with it and taking effective measures is important for all health care professionals (17). Maintaining body temperature during surgical interventions is an important component of safe and effective perioperative nursing care (18).

Researchers have investigated the effect of the prevention of perioperative hypothermia on thermal comfort $(12,14-16,19)$ and anxiety using active and/or passive heating methods at different time points in the perioperative period. Studies investigating the effectiveness of heating in reducing anxiety focused on the preoperative period; however, no consensus has yet been reached regarding the potential reduction of anxiety by the prevention of preoperative hypothermia $(12,15,19)$. In the present randomized controlled trials, gowns blowing warm air; heated blankets, fabrics, and liquid; and self-heating blankets were used for increasing thermal comfort. No common heating technique or heating area was used in these studies $(12,20-25)$. In this context, the primary purpose of the present study was to determine the effects of active (gown blowing warm air) and passive (heated blanket) heating on thermal comfort and anxiety in preoperative and postoperative periods in patients scheduled for open abdominal surgery.

This study primarily aims to determine the effects of active (gown blowing warm air) and passive (heated blanket) on thermal comfort and anxiety in preoperative and postoperative areas in patients scheduled for open abdominal surgery.

\section{Aims of the Study}

This study mainly aims to determine the effects of active (gown blowing warm air) and passive heating (heated blanket) techniques applied during preoperative and/or postoperative periods on the thermal comfort and anxiety levels of patients. This study also aims to determine the effects of active and passive heating used during different stages in the perioperative period on vital signs.

\section{Hypotheses}

$\mathrm{H} 1$ : There is a difference in thermal comfort and anxiety levels between patients heated with gown

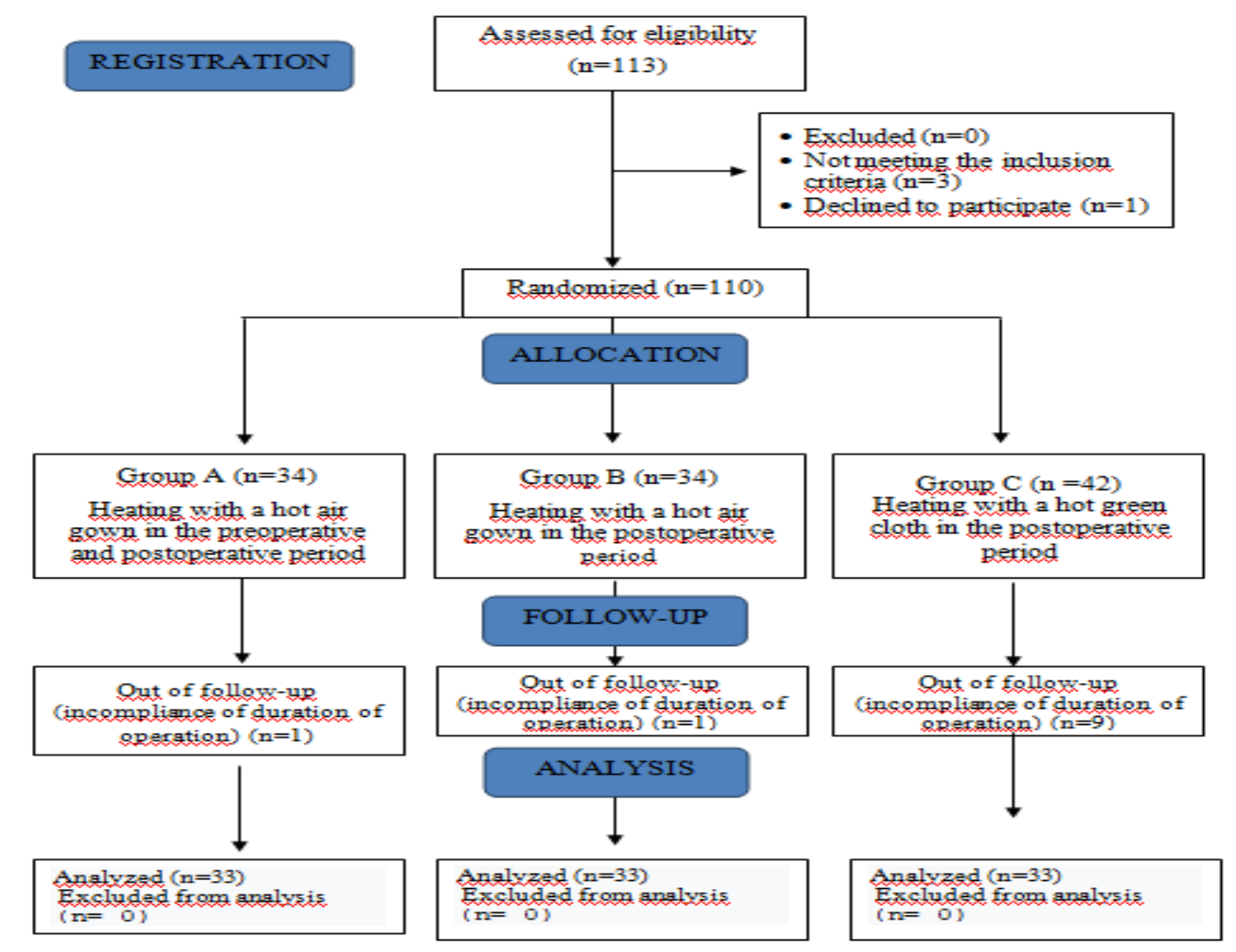

Figure 1. CONSORT diagram 
blowing warm air or heated blanket in the preoperative period.

$\mathrm{H} 2$ : There is a difference in thermal comfort and anxiety levels between patients heated with gown blowing warm air or heated blanket both in the preoperative and postoperative periods.

H3: There is a difference in thermal comfort and anxiety levels between patients heated with gown blowing warm air or heated blanket in the postoperative period.

$\mathrm{H} 4$ : There is a difference between the thermal comfort and anxiety levels of patients warmed with gown blowing warm air during both preoperative and postoperative periods and patients who are warmed only with gown blowing warm air in the postoperative period.

H5: There is a difference in vital signs between patients warmed with blowing warm air or a heated blanket in the preoperative and / or postoperative period.

\section{MATERIAL AND METHODS \\ Design and seting}

This study was a randomized, controlled trial, and the recommendations of the CONSORT checklist were followed (26) (Figure 1). Furthermore, it was conducted with patients admitted to the teaching hospital for open abdominal surgery between October 1, 2018, and January 10, 2019.

The sample size was calculated using G Power. Based on the values obtained by Wen et al. (2009), which is a similar study, we determined that 24 subjects should be included in each study group according to the sample size calculation with $5 \%$ alpha error, medium effect (0.7) size, and $80 \%$ power (G Power 3.1.9.2) (19). For performing parametric tests and considering the possibility of sample loss, the study was conducted with 110 subjects. Based on the findings obtained after the completion of the study, we determined that 99 samples were sufficient in the study using the G Power 3.1 software with an error margin of $5 \%$, power size of 0.8 , and effect size of $d=0.160$.

Patients meeting the inclusion criteria were divided into three groups using a randomization process. Blinding was not possible in this study, as patients would notice whether they were warming up or not. Therefore, blinding could not be done in the study. The randomization procedure was performed by a nurse who was not involved in the research at the clinic. The envelope drawing method was used for randomization in this study. Pieces of paper equal to the number of samples were cut. Group A, Group B, and Group $C$ (the control group) were inscribed on the

\begin{tabular}{|c|c|c|c|}
\hline $\begin{array}{l}\text { oे } \\
\text { के }\end{array}$ & \multicolumn{3}{|c|}{$\begin{array}{l}\text { Determining the sample suitable for the criteria } \\
\text { Obtaining patient consent }\end{array}$} \\
\hline \multirow{2}{*}{$\begin{array}{l}\text { N } \\
\frac{0}{d !} \\
\dot{\omega}\end{array}$} & \multicolumn{3}{|c|}{$\begin{array}{c}\text { Application of data collection tools } \\
\text { (Descriptive Characteristics Data Sheet, VAS, Anxiety Scale ) } \\
\text { Randomization }\end{array}$} \\
\hline & $\begin{array}{l}\text { Group A } \\
\text { Dressing of warm air blowing aprons in } \\
\text { the preoperative and postoperative } \\
\text { period }\end{array}$ & $\begin{array}{l}\text { Group B } \\
\text { Dressing of warm air blowing } \\
\text { aprons in the postoperative } \\
\text { period }\end{array}$ & $\begin{array}{l}\text { Group C } \\
\text { Warming with warmed } \\
\text { green cover in the } \\
\text { postoperative period }\end{array}$ \\
\hline $\begin{array}{l}m \\
\frac{0}{0} \\
\text { के }\end{array}$ & \multicolumn{3}{|c|}{ Warming patients according to their group in the preoperative period } \\
\hline $\begin{array}{l}\text { ¿े } \\
\stackrel{\circ}{0}\end{array}$ & \multicolumn{3}{|c|}{$\begin{array}{l}\text { Hospital routine in the intraoperative period } \\
\text { Taking vital signs and measuring thermal comfort level in the intraoperative period }\end{array}$} \\
\hline $\begin{array}{l}\text { ம0 } \\
\frac{0}{0} \\
\text { के }\end{array}$ & \multicolumn{3}{|c|}{$\begin{array}{l}\text { Warming the patient in the postoperative period } \\
\text { Follow-up of vital signs } \\
\text { Measuring thermal comfort and anxiety level when the patient begins to communicate }\end{array}$} \\
\hline
\end{tabular}

Figure 2. Application scheme 
pieces of paper. No statistically significant differences were noted in the demographic characteristics and anesthetic/surgical details between the three groups (Table 1). All papers were placed in a bag, and one piece of paper was drawn for each patient when they arrived. Patients were included in the group that was indicated on the piece of paper drawn for them. Patients were randomly allocated into three groups as follows: Group A ( $n=34)$, Group B $(n=34)$, and Group $C$ (control group; $n=42$ ). In the study, 1 patient in group $A$ and group $B$ and 9 patients in the control group were removed from the study as the duration of their operation was less than $2 \mathrm{~h}$. The research was completed with 99 patients. This study was completed with a total of 99 patients, 33 in each group. Blinding could not be done in this study because blowing warm was used in the study and the patients could notice whether there was a temperature.

Study inclusion criteria were as follows: scheduled for open abdominal surgery, an inpatient in the obstetrics and gynecology ward, 2-4 h surgery duration, 1 and 2 ASA scores, able to speak Turkish and 18-65 years of age. Study exclusion criteria were as follows: cognitive impairment, the presence of severe lesions or wounds on the skin, and alcohol and drug addiction. Criteria for discontinuing the study were as follows: conditions that caused patients to become hypothermic again, such as reoperation of the patient, undergoing anesthesia again, and massive hemorrhage; conditions that hindered receiving of information from the patient, such as unconsciousness; and the patient's voluntary decision to discontinue the study at any stage. Intervention Group A and B: Gowns blowing warm air (Bair Paws Model 875 Warming Unit and Bair Paws Warming Gowns) were used as intervention tools in the study. The temperature of these gowns was controlled by the patient. The patients increased or decreased the temperature based on whether they were feeling cold or warm, respectively. The gowns heat up to a maximum of $43^{\circ} \mathrm{C}$. Patients were dressed in the gowns approximately 45 min before surgery in the preoperative period. In the postoperative period, patients wore the gowns blowing warm air-up for an average of $1 \mathrm{~h}$.

- $\quad$ Patients in Group A were warmed using a gown blowing warm air starting at least 30 min before to the surgery until they were anesthetized. In the clinic, patients were dressed in warming gowns instead of operating gowns. The patients were started to be warmed with warming gowns. Routine hospital procedure was performed during the intraoperative period. In the postoperative period, the patients were again warmed using a gown blowing warm air after they were transferred to the post-anesthesia care unit and warming continued based on the temperature set by the patients until they wore their clothes in the ward.

- $\quad$ Routine care was provided for the patients in Group B in the preoperative and intraoperative periods. In the postoperative period, patients were

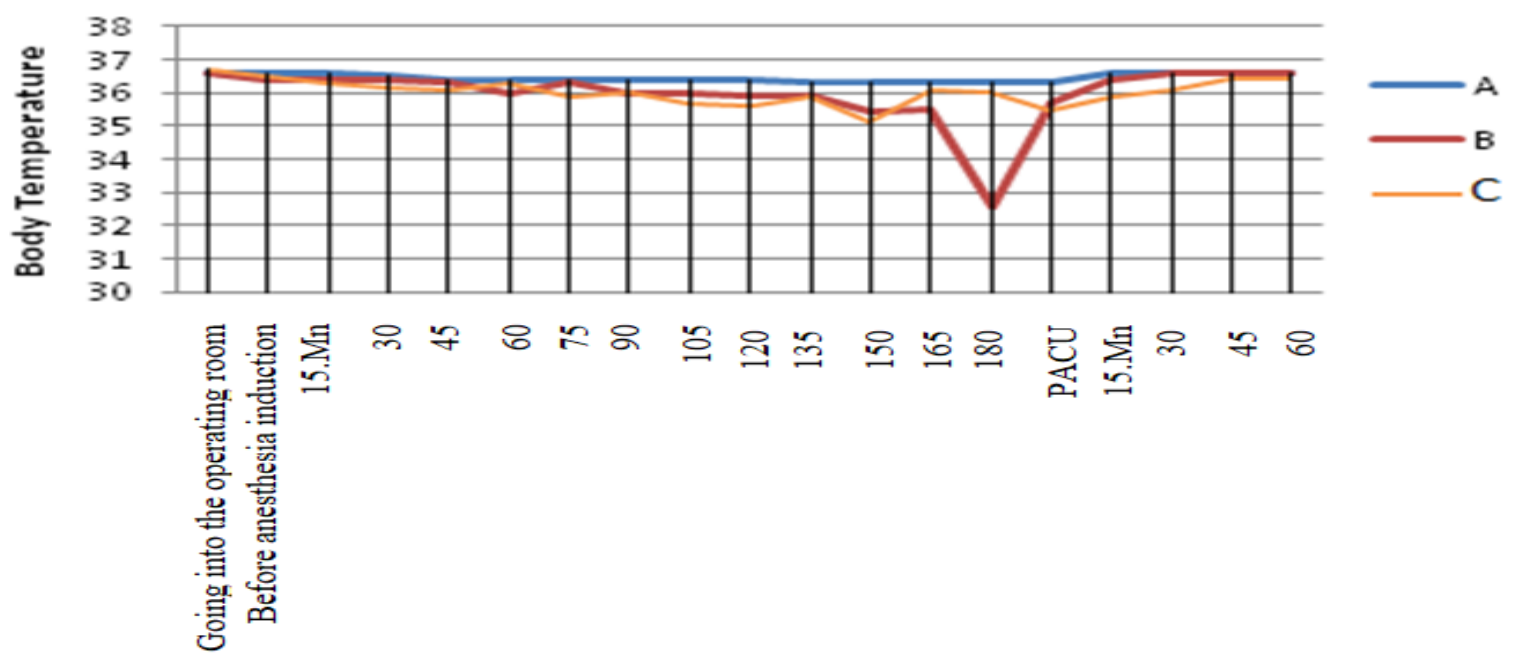

Figure 2. Dense intraabdominal adhesions and fibrous reactive tissue in a rat from control group is prominent. 
warmed up using the gown blowing warm air after they were transferred to the post-anesthesia care unit and the warming continued based on the temperature set by the patients until they wore their clothes in the ward.

Procedural care (Group C): The patients in this group received routine hospital care. Routine hospital care is as follows: The patients scheduled for surgery were dressed in surgical gowns in the clinic, placed on a stretcher, covered with a quilt (room temperature), and transferred to the operating room. Active heating system (Med Warm W300 brand) was used as part of the routine practice on all operating tables and was kept constant at $40^{\circ} \mathrm{C}$ until the completion of the surgical procedure. All patients included in the study were heated with the active heating system that was placed under the patient during the intraoperative period. After the completion of the surgical procedure, the patients were covered with the standard hospital quilt, transferred to the post-anesthesia care unit in a stretcher, and monitored. In the post-anesthesia care unit, the patients were covered with a cotton blanket heated at $100^{\circ} \mathrm{C}$ in an incubator. When the patient arrived at the clinic, they were dressed and covered with standard cotton blankets at room temperature. The patients in this group were met by the researcher, but no experimental application was made to this group (Figure 2).

The researcher herself carried out the procedures for welcoming the patient and putting on the aprons.

\section{Data collection}

In the preoperative period, the vital signs, thermal comfort, and anxiety levels of the patients were evaluated. Among the vital signs of the patients, body temperature was measured in the temporal region using an ARMOLINE non-contact infrared forehead thermometer, saturation and pulse were measured using an oximeter (plusMED-50DL finger clip pulse oximeter), and blood pressure was manually measured (Heine Gamma G5 Standard Sphygmomanometer). During this period, vital signs were collected from the patient file to avoid bias. The anxiety and thermal comfort scales were given to the patients by the researcher. The patients were asked to fill out the scales themselves.

In the intraoperative period, the vital signs and thermal comfort levels of the patients were evaluated. Just before anesthesia induction on the operating table, the patient was asked about the thermal comfort level. Body temperature was measured from the temporal region. Other vital signs were viewed from the monitor (Draeger patient monitor Delta Series).

Postoperative body temperature was measured from the temporal region. Other vital signs were taken from the monitor (philips mp20 monitor). The patients' thermal comfort and anxiety levels were re-evaluated immediately after the anesthesia effect was over and communication was initiated with the patient.

Calibration of the devices was performed by the hospital.

Descriptive Characteristics Data Sheet: It was prepared by the researcher based on the available literature $(12,20,24,27)$. This form consisted of 14 questions about the sociodemographic characteristics of the patients and their surgical intervention experiences. Vital signs follow-up form: The form was prepared by the researchers in the form of a chart. The patient's body temperature, diastolic blood pressure, systolic blood pressure, pulse, respiratory rate, saturation values were recorded in the perioperative period. In the preoperative period, the patient was taken on the way down to the operating room. In the intraoperative period, it was taken before anesthesia and every 15 minutes. It was taken in the postoperative period when he came to the post-anesthesia care unit and every 15 minutes. The vital signs of the patients were followed until the body temperature returned to normal.

Thermal Comfort Scale: In literature, researchers such as Q'Brien et al. (2010), Koeter et al. (2013), Akhtar et al. (2016), and Torossian et al. (2016) used Numerical Rating Scale (NRS) to evaluate thermal comfort $(12,20,23,25)$. Thus, the thermal comfort level was evaluated in the present study with NRS. The point system was explained to the patients, with 1 indicating "no comfort" and 10 indicating "the highest level of comfort," and then they were asked to rate their comfort levels.

State Trait Anxiety Inventory: The state-trait anxiety inventory developed by Spielberger et al. (1970) was used to measure the anxiety levels of the patients. The state anxiety inventory evaluates "how one feels at a certain moment and under certain conditions," whereas the continuous anxiety inventory evaluates "how one feels irrespective of the circumstances and conditions that he or she is in." Turkish validityreliability was performed by Oner and Le. In answering the state inventory, it is required to select and mark one of the options '1-not at all', '2-some', '3a lot', and '4-completely'. In the scoring of the 
inventory, 10 items $(3,4,6,7,9,12,13,14,17$ and 18) are direct and 10 items $(1,2,5,8,10,11,15,16$, 19 and 20) are used in reverse. In the Trait Anxiety Inventory, there are reversed statements in 7 items (items 21, 26, 27, 30, 33, 36, and 39). While 'reverse' statements expressing positive emotions are scored, those with a weight of 1 are converted to 4 , and those with a weight of 4 are converted to 1 . In direct expressions expressing negative emotions, responses with a value of 4 indicate the height of anxiety. Conversely, responses with a value of 4 indicate a low level of anxiety, and responses with a value of 1 indicate a high level of anxiety. Scores range from 20 to 80 points. There are no breakpoints in the scale. A high score is an indicator of a high anxiety level (28).

\section{Ethical considerations}

Necessary permissions were obtained from the ethics committee (number 71146310-511.06-E.196009) and the hospital where the study was conducted. In addition, written consent was obtained from the volunteers. Written informed consent was obtained when patients came to the clinic for hospitalization. It conforms to the provisions of the Declaration of Helsinki in 1995. Clinical trials number of the study: NCT04244071.

\section{Data analysis}

SPSS (IBM SPSS Statistics 22) software was used for statistical analysis. ANOVA, Tukey, or Tamhane test were used for measurements with normal distribution; Kruskal-Wallis "H" test, Friedman test, and Bonferroni correction were used for measurements with non-normal distribution. Effect size (d) and confidence interval calculations were performed. The results were evaluated at a significance level of $p<0.05$. Vital signs were measured every $15 \mathrm{~min}$ in the intraoperative and postoperative period. Body temperature data are shown in Figure 2. Mean values of vital signs measured every $15 \mathrm{~min}$ (preoperative, intraoperative, and postoperative periods) were calculated. These mean values were compared and evaluated between groups and are shown in Table 3. In data analysis, modified treatment ( $\mathrm{mlTT}$ ), and control analyses were performed with the intention of treatment.

\section{Validity and reliability/Rigor}

In the present study, Cronbach's a coefficient was 0.79 for the preoperative period continuous anxiety inventory and 0.89 for the preoperative and postoperative period state anxiety inventory.

\section{RESULTS}

No statistically significant differences were noted in the demographic characteristics and anesthetic/surgical details between the three groups (Table 1).

\section{Results of Thermal Comfort Levels}

Intra- and inter-group comparisons of the thermal comfort levels in the study group in the preoperative, intraoperative, and postoperative periods are presented in Table 2. No difference was noted in the thermal comfort levels between the groups in the

Table 1. Patient Characteristics, Perioperative and Surgical Variables

\begin{tabular}{|c|c|c|c|c|}
\hline Variables & Group A (n=33) & Group B (n=33) & Group C (n=33) & $\mathbf{p}$ \\
\hline Age (year) & $45,73 \pm 8,98$ & $47,85 \pm 7,24$ & $47,67 \pm 9,96$ & $0,800^{*}$ \\
\hline BMI $\left(\mathrm{kg} / \mathrm{m}^{2}\right)$ & $28,94 \pm 4,20$ & $29,09 \pm 5,10$ & $27,15 \pm 3,40$ & $0,129 * *$ \\
\hline Trait anxiety score & $44,58 \pm 8,15$ & $46,39 \pm 6,65$ & $46,55 \pm 6,10$ & $0,464^{*}$ \\
\hline $\begin{array}{l}\text { Duration of surgical } \\
\text { intervention }(\mathrm{mn})\end{array}$ & $124,52 \pm 8,71$ & $127,45 \pm 12,49$ & $124,15 \pm 7,54$ & $0,635^{*}$ \\
\hline Duration of anesthesia (mn) & $137,70 \pm 10,47$ & $139,21 \pm 11,40$ & $137,30 \pm 7,20$ & $0,950^{*}$ \\
\hline $\begin{array}{l}\text { Amount of intraoperative } \\
\text { fluid (ml) }\end{array}$ & $2363,64 \pm 259,59$ & $2233,33 \pm 266,54$ & $2254,55 \pm 258,71$ & $0,109^{*}$ \\
\hline \multicolumn{5}{|l|}{ Presence of chronic illness } \\
\hline Yes & $12(36,4 \%)$ & $11(33,3 \%)$ & $8(24,2 \%)$ & \multirow{2}{*}{$0,543^{* * *}$} \\
\hline No & $21(63,6 \%)$ & $22(66,7 \%)$ & $25(75,8 \%)$ & \\
\hline \multicolumn{5}{|c|}{ State of having undergone an operation before } \\
\hline Yes & $20(60,6 \%)$ & $22(66,7 \%)$ & $21(65,6 \%)$ & \multirow{2}{*}{$0,860^{* * *}$} \\
\hline No & $13(39,4 \%)$ & $11(33,3 \%)$ & $11(34,4 \%)$ & \\
\hline
\end{tabular}


Table 2. Perioperative period thermal comfort and anxiety levels of the study group

\begin{tabular}{|c|c|c|c|c|c|c|c|}
\hline & \multicolumn{7}{|c|}{ Thermal Comfort Levels } \\
\hline & Group A ${ }^{(1)}$ & \multicolumn{2}{|c|}{ Group B ${ }^{(2)}$} & \multicolumn{2}{|c|}{ Group C ${ }^{(3)}$} & \multirow{2}{*}{$\begin{array}{l}\mathrm{p} \\
\text { (differenc } \\
\mathrm{e})\end{array}$} & \multirow[b]{2}{*}{$d$} \\
\hline & $\begin{array}{ll}\overline{\mathrm{X}} \pm \mathrm{Ss} & \text { Median[I } \\
& \mathrm{QR}]\end{array}$ & $\overline{\mathrm{X}} \pm \mathrm{ss}$ & $\begin{array}{l}\text { Median } \\
\text { [IQR] }\end{array}$ & $\overline{\mathrm{X}} \pm \mathrm{ss}$ & $\begin{array}{l}\text { Median } \\
{[\mathrm{IQR}]}\end{array}$ & & \\
\hline $\begin{array}{l}\text { Preoperative } \\
\text { period (a) }\end{array}$ & $\begin{array}{l}9,51 \pm 0 \\
, 51\end{array}$ & $\begin{array}{l}9,33 \pm 0 \\
48\end{array}$ & $9,0[1,0]$ & $\begin{array}{l}9,33 \pm 0,4 \\
8\end{array}$ & $9,0[1,0]$ & 0,221 & $\begin{array}{l}0,262 \\
(-0,157 \\
0,681) \\
\end{array}$ \\
\hline $\begin{array}{l}\text { Intraoperative } \\
\text { period (b) }\end{array}$ & $\begin{array}{l}9,03 \pm 1 \\
, 19\end{array}$ & $\begin{array}{l}3,79 \pm 1 \\
58\end{array}$ & $4,0[2,0]$ & $\begin{array}{l}3,52 \pm 1,0 \\
3\end{array}$ & $4,0[1,0]$ & $\begin{array}{l}0,000 \\
{[1>2=3]^{*}}\end{array}$ & $\begin{array}{l}1,145 \\
(0,698 ;- \\
1,593)\end{array}$ \\
\hline $\begin{array}{l}\text { Postoperative } \\
\text { period (c) }\end{array}$ & $\begin{array}{l}9,15 \pm 0 \\
, 76\end{array}$ & $\begin{array}{l}7,48 \pm 1 \\
25\end{array}$ & $7,0[1,5]$ & $\begin{array}{l}2,33 \pm 1,4 \\
3\end{array}$ & $2,0[2,0]$ & $\begin{array}{l}p=0,000 \\
{[1>2>3]^{*}}\end{array}$ & $\begin{array}{l}2,174 \\
(1,658 ;- \\
2,690) \\
\end{array}$ \\
\hline$p$ (difference) & $0,039 \quad[a>b=c]$ & 0,000 & $>c>b]$ & \multirow{2}{*}{\multicolumn{2}{|c|}{$\begin{array}{l}0,000 \quad[\mathbf{a}>\mathbf{b}>\mathbf{c}] \\
0,485(0,062 ; 0,909)\end{array}$}} & & \\
\hline \multirow[t]{2}{*}{ d } & $\begin{array}{l}0,213(-0,206 \\
0,632)\end{array}$ & \multicolumn{2}{|c|}{$0,726(0,296 ; 1,156)$} & & & & \\
\hline & \multicolumn{3}{|l|}{ Anxiety Levels } & & & & \\
\hline $\begin{array}{l}\text { Preoperative } \\
\text { period }\end{array}$ & $\begin{array}{l}48,85 \pm \\
9,60\end{array}$ & $\begin{array}{l}55,48 \pm 5 \\
95\end{array}$ & $55,0[6,5]$ & $\begin{array}{l}49,30 \pm 8 \\
95\end{array}$ & $\begin{array}{l}50,0 \\
{[12,0]}\end{array}$ & $\begin{array}{l}0,002 \\
{[2>1=3]}\end{array}$ & $\begin{array}{l}0,344 \\
(-0,076 \\
0,765) \\
\end{array}$ \\
\hline $\begin{array}{l}\text { Postoperative } \\
\text { period }\end{array}$ & $\begin{array}{l}36,76 \pm \\
5,42\end{array}$ & $\begin{array}{l}40,15 \pm 4 \\
94\end{array}$ & $40,0[7,5]$ & $\begin{array}{l}50,12 \pm 6 \\
40\end{array}$ & $\begin{array}{l}51,0 \\
{[6,8]}\end{array}$ & $\begin{array}{l}0,000 \\
{[1<2<3]}\end{array}$ & $\begin{array}{l}-2,078 \\
(-2,587 ;- \\
1,570)\end{array}$ \\
\hline$p$ (difference) & \multirow{2}{*}{$\begin{array}{l}0,000 \\
4,263(3,029 \\
5,497)\end{array}$} & \multicolumn{2}{|l|}{0,000} & \multicolumn{2}{|c|}{0,649} & & \\
\hline d & & \multicolumn{2}{|c|}{$4,664(3,348 ; 5,980)$} & \multicolumn{2}{|c|}{$\begin{array}{l}-0,160(-0,844 \\
0,523)\end{array}$} & & \\
\hline
\end{tabular}

preoperative period ( $p>0.05$ ). We found that during the intraoperative period, the thermal comfort levels of the patients in Group A were higher than those in Groups B and C and that the thermal comfort levels of the patients in Groups B and C were similar $(p<$ 0.05). In the postoperative period, we found that the thermal comfort levels in Group A were higher than those in Groups B and C and that the thermal comfort levels in Group B were higher compared with those in Group C ( $p<0.05)$.

The evaluation of thermal comfort levels within the groups revealed that the thermal comfort level of all groups was the highest in the preoperative period. In Group A, intraoperative and postoperative comfort levels were equal. Moreover, the postoperative thermal comfort level of Group B was more than two times higher than in the intraoperative period. In Group C, the lowest thermal comfort level was in the postoperative period. A difference of more than four times was present between preoperative and postoperative thermal comfort levels of Group C.

Results of Anxiety Levels

Intra- and inter-group comparisons of anxiety levels in the study group in the preoperative and postoperative periods are presented in Table 2.
In the preoperative period, the anxiety levels of the patients in Group B were higher than those in Groups $A$ and $C$. In the postoperative period, the anxiety levels of the patients in Group A were lower than those in Group B, C, and the anxiety levels of the patients in Group B were lower than those in Group C $(p<0.05)$. There was a 3.39 point difference in the anxiety scores between Groups A, B and 14.24 point difference was observed between Groups A and C.

\section{Results of Vital Signs}

The preoperative, intraoperative, and postoperative vital sign results of the study group are presented in Table 3. Body temperatures of the study groups were similar in the preoperative period $(p>0.05)$. In the intraoperative period, the body temperatures of the patients in Groups B and C were equal and lower than those in Group A. The body temperature of patients in Group A was approximately $0.4^{\circ} \mathrm{C}$ higher than that in Group C. In the postoperative period, the highest body temperature was observed in the patients in Group A ( $p<0.05)$. The body temperature of patients in Group B was higher than that in Group C. A difference of $0.13^{\circ} \mathrm{C}$ was detected between the body temperature of Groups A and B. A difference of $0.46^{\circ} \mathrm{C}$ was detected between Groups $\mathrm{A}$ and $\mathrm{C}$. 
Table 3. Perioperative period vital signs of the patients

\begin{tabular}{|c|c|c|c|c|c|c|c|c|}
\hline & \multicolumn{2}{|c|}{ Group A (n=33) (1) } & \multicolumn{2}{|c|}{ Group B $(n=33)(2)$} & \multicolumn{2}{|c|}{ Group C (n=33) ${ }^{(3)}$} & \multirow{2}{*}{$\begin{array}{l}p \\
\text { (difference) }\end{array}$} & \multirow[b]{2}{*}{ d } \\
\hline & $\overline{\mathbf{x}} \pm \mathbf{s s}$ & $\begin{array}{l}\text { Median } \\
\text { [IQR] }\end{array}$ & $\overline{\mathbf{x}} \pm \mathbf{s s}$ & $\begin{array}{l}\text { Median } \\
\text { [IQR] }\end{array}$ & $\overline{\mathbf{x}} \pm \mathbf{s s}$ & $\begin{array}{l}\text { Median } \\
{[\mathrm{IQR}]}\end{array}$ & & \\
\hline \multicolumn{9}{|c|}{ Body Temperature } \\
\hline $\begin{array}{l}\text { Preoperative } \\
\text { period }\end{array}$ & $36,67 \pm 0,16$ & $\begin{array}{l}36,6 \\
{[0,1]}\end{array}$ & $36,63 \pm 0,20$ & $\begin{array}{l}36,6 \\
{[0,3]}\end{array}$ & $36,58 \pm 0,17$ & $\begin{array}{l}36,6 \\
{[0,3]}\end{array}$ & 0,20 & $\begin{array}{l}0,264(-0,155 \\
0,684)\end{array}$ \\
\hline $\begin{array}{l}\text { Intraoperative } \\
\text { period }\end{array}$ & $36,42 \pm 0,16$ & $\begin{array}{l}36,5 \\
{[0,2]}\end{array}$ & $36,16 \pm 0,26$ & $\begin{array}{l}36,2 \\
{[0,3]}\end{array}$ & $36,05 \pm 0,28$ & $\begin{array}{l}36,1 \\
{[0,4]}\end{array}$ & $\begin{array}{l}0,00 \\
{[1>2=3]}\end{array}$ & $\begin{array}{l}1,388(0,928 \\
1,849)\end{array}$ \\
\hline $\begin{array}{l}\text { Postoperative } \\
\text { period }\end{array}$ & $36,53 \pm 0,12$ & $\begin{array}{l}36,5 \\
{[0,1]}\end{array}$ & $36,35 \pm 0,14$ & $\begin{array}{l}36,4 \\
{[0,2]}\end{array}$ & $36,07 \pm 0,15$ & $\begin{array}{l}36,1 \\
{[0,2]}\end{array}$ & $\begin{array}{l}0,00 \\
{[1>2>3]}\end{array}$ & $\begin{array}{l}2,331(1,802 ; \\
2,860)\end{array}$ \\
\hline \multicolumn{9}{|c|}{ Systolic Blood Pressure } \\
\hline $\begin{array}{l}\text { Preoperative } \\
\text { period }\end{array}$ & $115,97 \pm 12,07$ & $\begin{array}{l}110,0 \\
{[20,0]}\end{array}$ & $113,93 \pm 10,59$ & $\begin{array}{l}110,0 \\
{[10,0]}\end{array}$ & $121,55 \pm 10,00$ & $\begin{array}{l}120,0 \\
{[20,0]}\end{array}$ & $\begin{array}{l}0,025 \\
{[1=2<3]}\end{array}$ & $\begin{array}{l}-0,793(-1,225 \\
0,360)\end{array}$ \\
\hline $\begin{array}{l}\text { Intraoperative } \\
\text { period }\end{array}$ & $110,09 \pm 10,04$ & $\begin{array}{l}109,6 \\
{[16,6]}\end{array}$ & $113,95 \pm 14,55$ & $\begin{array}{l}113,0 \\
{[20,4]} \\
\end{array}$ & $112,99 \pm 7,79$ & $\begin{array}{l}112,0 \\
{[8,6]}\end{array}$ & 0,347 & $\begin{array}{l}-0,087(-0,505 ; \\
0,331)\end{array}$ \\
\hline $\begin{array}{l}\text { Postoperative } \\
\text { period }\end{array}$ & $124,16 \pm 9,22$ & $\begin{array}{l}123,4 \\
{[10,9]} \\
\end{array}$ & $124,06 \pm 14,95$ & $\begin{array}{l}121,4 \\
{[26,1]} \\
\end{array}$ & $122,32 \pm 14,39$ & $\begin{array}{l}124,0 \\
{[11,5]}\end{array}$ & 0,860 & $\begin{array}{l}0,167(-0,253 \\
0,584)\end{array}$ \\
\hline \multicolumn{9}{|c|}{ Diastolic Blood Pressure } \\
\hline $\begin{array}{l}\text { Preoperative } \\
\text { period }\end{array}$ & $72,52 \pm 7,67$ & $\begin{array}{l}70,0 \\
{[10,0]}\end{array}$ & $69,39 \pm 7,88$ & $\begin{array}{l}70,0 \\
{[10,0]}\end{array}$ & $72,79 \pm 6,73$ & $\begin{array}{l}70,0 \\
{[10,0]}\end{array}$ & 0,102 & $\begin{array}{l}-0,361(- \\
0,782 ; 0,060)\end{array}$ \\
\hline $\begin{array}{l}\text { Intraoperative } \\
\text { period }\end{array}$ & $67,27 \pm 7,71$ & $\begin{array}{l}66,5 \\
{[9,8]} \\
\end{array}$ & $68,77 \pm 8,62$ & $\begin{array}{l}69,2 \\
{[14,3]}\end{array}$ & $69,37 \pm 9,13$ & $\begin{array}{l}66,3 \\
{[9,3]}\end{array}$ & 0,678 & $\begin{array}{l}-0,192(-0,611 ; \\
0,227)\end{array}$ \\
\hline $\begin{array}{l}\text { Postoperative } \\
\text { period }\end{array}$ & $72,66 \pm 7,01$ & $\begin{array}{l}72,4 \\
{[10,5]}\end{array}$ & $73,02 \pm 8,81$ & $\begin{array}{l}74,0 \\
{[11,0]}\end{array}$ & $72,51 \pm 6,25$ & $\begin{array}{l}72,0 \\
{[4,8]}\end{array}$ & 0,582 & $\begin{array}{l}0,228(-0,191 ; \\
0,647)\end{array}$ \\
\hline \multicolumn{9}{|l|}{ Pulse } \\
\hline $\begin{array}{l}\text { Preoperative } \\
\text { period }\end{array}$ & $78,30 \pm 8,56$ & $\begin{array}{l}77,0 \\
{[8,5]}\end{array}$ & $79,97 \pm 6,45$ & $\begin{array}{l}78,0 \\
{[10,5]}\end{array}$ & $80,30 \pm 9,77$ & $\begin{array}{l}80,0 \\
{[16,5]}\end{array}$ & 0,32 & $\begin{array}{l}-0,285(- \\
0,705 ; 0,135)\end{array}$ \\
\hline $\begin{array}{l}\text { Intraoperative } \\
\text { period }\end{array}$ & $67,50 \pm 6,93$ & $\begin{array}{l}65,8 \\
{[6,1]}\end{array}$ & $67,62 \pm 7,33$ & $\begin{array}{l}65,9 \\
{[8,2]}\end{array}$ & $75,89 \pm 9,84$ & $\begin{array}{l}73,1 \\
{[15,8]}\end{array}$ & $\begin{array}{l}0,00 \\
{[1=2<3]}\end{array}$ & $\begin{array}{l}-1,210(- \\
1,661 ; 0,760)\end{array}$ \\
\hline $\begin{array}{l}\text { Postoperative } \\
\text { period }\end{array}$ & $67,32 \pm 4,04$ & $\begin{array}{l}67,0 \\
{[6,5]}\end{array}$ & $69,05 \pm 6,60$ & $\begin{array}{l}66,8 \\
{[11,9]}\end{array}$ & $75,61 \pm 8,81$ & $\begin{array}{l}76,2 \\
{[9,4]} \\
\end{array}$ & $\begin{array}{l}0,00 \\
{[1=2<3]}\end{array}$ & $\begin{array}{l}-1,344(- \\
1,802 ;-0,887)\end{array}$ \\
\hline \multicolumn{9}{|c|}{ Respiratory Rate } \\
\hline $\begin{array}{l}\text { Preoperative } \\
\text { period }\end{array}$ & $18,65 \pm 1,66$ & $\begin{array}{l}18,0 \\
{[2,0]}\end{array}$ & $18,55 \pm 1,15$ & $\begin{array}{l}18,0 \\
{[2,0]}\end{array}$ & $18,73 \pm 1,21$ & $\begin{array}{l}18,0 \\
{[2,0]}\end{array}$ & 0,813 & $\begin{array}{l}-0,162(-0,579 \\
0,257)\end{array}$ \\
\hline $\begin{array}{l}\text { Intraoperative } \\
\text { period }\end{array}$ & $19,39 \pm 2,08$ & $\begin{array}{l}20,0 \\
{[2,0]}\end{array}$ & $19,70 \pm 1,24$ & $\begin{array}{l}20,0 \\
{[0,0]}\end{array}$ & $19,33 \pm 1,98$ & $\begin{array}{l}20,0 \\
{[2,0]}\end{array}$ & 0,692 & $\begin{array}{l}0,162(-0,257 ; \\
0,580)\end{array}$ \\
\hline $\begin{array}{l}\text { Postoperative } \\
\text { period }\end{array}$ & $18,82 \pm 1,24$ & $\begin{array}{l}18,8 \\
{[1,6]}\end{array}$ & $18,59 \pm 0,97$ & $\begin{array}{l}18,8 \\
{[1,7]} \\
\end{array}$ & $17,98 \pm 0,84$ & $\begin{array}{l}18,0 \\
{[0,8]}\end{array}$ & $\begin{array}{l}0,005 \\
{[1=2>3]}\end{array}$ & $\begin{array}{l}0,955(0,517 ; \\
1,394)\end{array}$ \\
\hline \multicolumn{9}{|l|}{ Saturation } \\
\hline $\begin{array}{l}\text { Preoperative } \\
\text { period }\end{array}$ & $97,39 \pm 1,37$ & $\begin{array}{l}98,0 \\
{[1,0]}\end{array}$ & $96,67 \pm 1,49$ & $\begin{array}{l}97,0 \\
{[2,0]}\end{array}$ & $97,60 \pm 1,17$ & $\begin{array}{l}98,0 \\
{[1,0]}\end{array}$ & $\begin{array}{l}0,005 \\
{[1=3>2]}\end{array}$ & $\begin{array}{l}-0,665(- \\
1,093 ;-0,237)\end{array}$ \\
\hline $\begin{array}{l}\text { Intraoperative } \\
\text { period }\end{array}$ & $98,03 \pm 1,65$ & $\begin{array}{l}98,0 \\
{[2,5]}\end{array}$ & $98,09 \pm 1,70$ & $\begin{array}{l}98,0 \\
{[4,0]}\end{array}$ & $97,64 \pm 1,29$ & $\begin{array}{l}97,0 \\
{[2,0]}\end{array}$ & 0,391 & $\begin{array}{l}0,410(-0,012 \\
0,832)\end{array}$ \\
\hline $\begin{array}{l}\text { Postoperative } \\
\text { period }\end{array}$ & $96,53 \pm 3,22$ & $\begin{array}{l}97,0 \\
{[1,3]}\end{array}$ & $96,43 \pm 1,62$ & $\begin{array}{l}96,6 \\
{[1,5]}\end{array}$ & $97,21 \pm 3,43$ & $\begin{array}{l}96,8 \\
{[1,0]}\end{array}$ & 0,238 & $\begin{array}{l}-0,498(-0,921 \\
-0,074)\end{array}$ \\
\hline
\end{tabular}

Values are expressed as $n(\%)$, mean \pm SD. None of the differences was significant $(p>0.05)$.

${ }^{*}$ Kruskall Wallis test for intergroup comparison.

In the preoperative period, systolic blood pressure values were similar in Groups $A$ and $B$ and were lower than those in Group $C(p<0.05)$. However, the systolic blood pressure of patients was within normal limits. No difference was noted among the groups in the intraoperative and postoperative periods $(p>$ 0.05). No difference was noted in the diastolic blood pressure values among the groups at three time points (preoperative, intraoperative, and postoperative period) $(p>0.05)$. No difference was noted in pulse values among the groups in the preoperative period $(p>0.05)$. In the intraoperative and postoperative periods, the pulse values of the patients in Groups A and B were significantly lower than those in Group $C(p<0.05)$. However, the pulse values of the groups were within the normal range. We determined that there was no difference in terms of their respiratory rates among the groups in the preoperative and intraoperative periods $(p>0.05)$ and that in the postoperative period, Groups A and B had similar values that were higher than those in Group C $(p<0.05)$. No anomalous findings were obtained in the respiratory numbers of the patients involved in the study. We also determined that in the preoperative period, Groups A and C had similar saturation values that were higher than those in Group B, while no difference was noted between the 
intraoperative and postoperative periods. Saturation values were also within normal limits.

The body temperature monitoring of the study groups evaluated for $15 \mathrm{~min}$ in the perioperative period is presented in Graph 1. The body temperature of the patients in Group A was above $36^{\circ} \mathrm{C}$ during the perioperative period. However, the body temperature of the patients decreased below $36^{\circ} \mathrm{C}$ at 90th min in Group C and at 105th min in Group B following anesthesia induction (Figure 2). In the postoperative period (post-anesthesia care unit), the body temperature was above $36^{\circ} \mathrm{C}$ at $15 \mathrm{~min}$ for patients in Group B and at 30th min for patients in Group C.

In the study, the body temperature of the patients was measured when they were included in the study (preoperative period), before anesthesia indication (intraoperative period), every $15 \mathrm{~min}$ during the operation, when patients arrived at postanesthesia care unit, and every $15 \mathrm{~min}$ during the research period (in the postoperative period) (Figure 2). During the intraoperative period, patients in Group A were normothermic and the body temperatures of patients in Groups B and C dropped below $36^{\circ} \mathrm{C}$ 90th min after anesthesia induction.

\section{DISCUSSION}

\section{Thermal Comfort Level}

The present study shows that active heating increases the thermal comfort levels of patients. In addition, the findings of this study reveal that active heating during both preoperative and postoperative periods is more effective in increasing thermal comfort compared to active heating only in the postoperative period. Studies investigating the effect of heating on thermal comfort in the preoperative, intraoperative, and postoperative periods $(12,24,29)$, in both preoperative and intraoperative periods and intraoperative periods $(30,31)$ have determined that heating increases thermal comfort. Another study has demonstrated that heating with gowns blowing warm air increases the thermal comfort level in patients undergoing cardiac catheterization under sedation (32). This study is similar to the findings in the literature that active heating increases thermal comfort. In the literature, there is no information on which area of the perioperative process active heating methods used to increase thermal comfort are more effective. This study has added new information to the literature in this respect.

\section{Anxiety Level}

This study demonstrated that heating during both preoperative and postoperative periods was more effective in reducing anxiety. There is limited literature present on the investigation of the efficacy of heating of patients on anxiety during the perioperative period. In the study performed by Kober et al. (2003), in which active and passive heating methods were used in the emergency department, active heating was determined to be effective in reducing anxiety (33). In another study conducted for the depression level in patients undergoing bypass surgery, anxiety levels were found to be lower in patients with normal body temperature in the postoperative period (34). Park and Choi (2010) concluded that the heating of patients scheduled for abdominal surgery using a warm air-blowing system in the preoperative period was effective in reducing anxiety (35). In the study of Kim et al. (2019), it was found that the heating pad applied during cystoscopy in female patients reduced anxiety (36). In contrast, some other studies indicated that heating in the preoperative $(15,19)$ and postoperative (12) periods does not effect on anxiety. However, one study concluded that patients with high levels of anxiety in the preoperative period have a higher risk of intraoperative hypothermia (37). The findings of the study are similar to the findings in the literature showing that the active warming method reduces anxiety. In addition, the conclusion that active warming in both preoperative and postoperative periods is more effective in reducing anxiety than active warming only in the preoperative period adds new information to the literature.

\section{Vital Signs}

In the preoperative period, no patient noted that they were cold. The risk of hypothermia in the preoperative period is caused by environmental and patient-related factors $(1,38)$. In the present study, environmental risk factors were kept under control as the patients wore their clothes on the surgical gowns and covered themselves with blankets in the preoperative period. However, the exclusion of individuals aged 65 years and above and preoperative hypothermia risk factors, such as add the of chronic disease, BMI, and age, were similar among the groups. The absence of a decrease in the body temperature in the preoperative period and the absence of a difference among the groups can be explained by these factors. 
The patients in Group A were normothermic during the intraoperative period, and the body temperature of the patients in Groups B and $C$ decreased below $36^{\circ} \mathrm{C}$ at 90th min following anesthesia induction. Similar to the results of this study, other studies have determined that active heating in the preoperative period is effective in preventing intraoperative hypothermia (39-42). In the study investigating the effectiveness of heating methods used in the prevention of postoperative hypothermia, the body temperature reached $36^{\circ} \mathrm{C}$ after $20-70 \mathrm{~min}$ (43). In this study, the achievement of normothermia in patients in Group B (15th min) and in Group C (30th min) is consistent with the studies that show that active heating has a positive effect on body reheating time $(24,43-45)$.

We found that heating using active heating methods during the perioperative period positively contributed to body temperature in the postoperative period, which supports the abovementioned study. Torossian et al. (2016) also concluded that active heating during the preoperative, intraoperative, and postoperative periods was effective in preventing hypothermia in the postoperative period (25). Based on this study and other study results, despite the difference in reheating times of the patients following surgery, we can conclude that the reheating time was shorter for patients for whom active heating was used compared to patients for whom passive heating or no heating was used.

In this study, blood pressure, pulse values, respiratory rate, and saturation values are within the normal range. It has been reported in the literature that hypothermia has an effect on vital signs $(16,46)$ and increases blood pressure and heart rate in the postoperative period $(47,48)$, and decreases pulse values (49). In addition, hypothermia has been reported to suppress the respiratory system (50), leading to a decrease in respiratory rate (51). Our results are not consistent with the available literature. This may be explained by the absence of severe hypothermia in the patients in the study.

\section{Limitations}

This study is limited to the hospital where the study was conducted, evaluations based on scales, patients' self-reports, and patients in the gynecology and obstetrics departments.

\section{CONCLUSION}

The body temperature of the patients who were heated by active heating in the preoperative period was within normal levels during the intraoperative period. Perception of comfort in the intraoperative and postoperative periods increased in patients who were heated with active heating during the preoperative period. Postoperative anxiety levels of patients who were heated with active heating during the preoperative and postoperative periods were lower. The effect of active and passive heating methods on the vital signs and reheating time of patients were examined, and the body temperature of the patients who were warmed up using active heating methods for at least $30 \mathrm{~min}$ during the preoperative period did not decrease below $36^{\circ} \mathrm{C}$ during surgery. Moreover, at the 30th min in the postoperative period, the body temperature of the patients who were warmed up only in the postoperative period equalized that of the patients who were also warmed up in the preoperative period. Patients who were heated with active heating from the preoperative period were protected from the negative effects of hypothermia. There was no difference in blood pressure, pulse, respiratory rate, and saturation between active and passive heating. We recommend that vital signs other than body temperature should be investigated in future studies with different heating techniques and for different sample groups.

This research was presented as an oral presentation at the 3rd International 11th National Congress of Turkish Surgery and Operating Room Nursing.

Author Contributions: Study design: PTT, SK, IK. Data collection PTT. Data analysis: PTT, SK, IK. Manuscript writing: PTT, SK, IK. Conflict of Interest: None.

Ethical Approval: Ethics committee approval was received for this research from the Ministry of Health Medical Devices Institution and Selcuk University Faculty of Medicine Interventional Ethics Committee (Date and no: (12.11.18, 71146310-511.06-E.19600).

Funding: It was supported by the Vehbi Koç Foundation Nursing Fund as project number 2018.1.11.

Peer-review: Externally peer-reviewed.

\section{REFERENCES}

1. Kurz A. Physiology of thermoregulation. Best Practice \& Research Clinical Anaesthesiology. 2008;22(4):627-44.

2. Mason SE, Kinross JM, Hendricks J, Arulampalam TH. Postoperative hypothermia 
and surgical site infection following peritoneal insufflation with warm, humidified carbon dioxide during laparoscopic colorectal surgery: a cohort study with cost-effectiveness analysis. Surgical endoscopy. 2017;31(4):1923-9.

3. Turkish Society of Anaesthesiology and Reanimation. Turkish Society of Anaesthesiology and Reanimation Practice Guideline for Prevention of Unintentional Perioperative Hypothermia. Turk J Anaesth Reanim. 2013;41:188-90.

4. Reynolds L, Beckmann J, Kurz A. Perioperative complications of hypothermia. Best practice \& research Clinical anaesthesiology. 2008;22(4):645-57.

5. Rajagopalan S, Mascha E, Na J, Sessler DI. The effects of mild perioperative hypothermia on blood loss and transfusion requirement. Anesthesiology: The Journal of the American Society of Anesthesiologists. 2008;108(1):71-7.

6. Good KK, Verble JA, Secrest J, Norwood BR. Postoperative hypothermia the chilling consequences. AORN journal. 2006;83(5):105466.

7. Kelly PA, Cooper SK, Krogh ML, Morse EC, Crandall CG, Winslow EH, et al. Thermal comfort and safety of cotton blankets warmed at $130^{\circ} \mathrm{F}$ and $200^{\circ} \mathrm{F}$. Journal of PeriAnesthesia Nursing. 2013;28(6):337-46.

8. Scott EM, Buckland R. A systematic review of intraoperative warming to prevent postoperative complications. AORN journal. 2006;83(5):1090113.

9. Scott EM, Leaper DJ, Clark M, Kelly PJ. Effects of warming therapy on pressure ulcers-a randomized trial. AORN journal. 2001;73(5):92138.

10. Walton-Geer PS. Prevention of pressure ulcers in the surgical patient. AORN journal. 2009;89(3):538-52.

11. Tsuei BJ, Kearney PA. Hypothermia in the trauma patient. Injury. 2004;35(1):7-15.

12. O'Brien D, Greenfield MLV, Anderson JE, Smith BA, Morris M. Comfort, satisfaction, and anxiolysis in surgical patients using a patientadjustable comfort warming system: a prospective randomized clinical trial. Journal of PeriAnesthesia Nursing. 2010;25(2):88-93.

13. Macario A, Dexter $F$. What are the most important risk factors for a patient's developing intraoperative hypothermia? Anesthesia \& Analgesia. 2002;94(1):215-20.

14. Frank SM, Raja SN, Bulcao CF, Goldstein DS. Relative contribution of core and cutaneous temperatures to thermal comfort and autonomic responses in humans. Journal of Applied physiology. 1999;86(5):1588-93.

15. Kimberger $O$, Illievich $U$, Lenhardt R. The effect of skin surface warming on pre-operative anxiety in neurosurgery patients. Anaesthesia. 2007;62(2):140-5.

16. Wagner D, Byrne M, Kolcaba K. Effects of comfort warming on preoperative patients. AORN journal. 2006;84(3):427-48.

17. Beyea SC. 2009 patient safety goals: a perioperative nursing priority. AORN journal. 2008;88(3):459-62.

18. Galvao CM, Marck PB, Sawada NO, Clark AM. A systematic review of the effectiveness of cutaneous warming systems to prevent hypothermia. Journal of clinical nursing. 2009;18(5):627-36.

19. Wen R, Leslie K, Rajendra P. Pre-operative forced-air warming as a method of anxiolysis. Anaesthesia. 2009;64(10):1077-80.

20. Akhtar Z, Hesler BD, Fiffick AN, Mascha EJ, Sessler DI, Kurz A, et al. A randomized trial of prewarming on patient satisfaction and thermal comfort in outpatient surgery. Journal of clinical anesthesia. 2016;33:376-85.

21. Bernardis RCGD, Siaulys MM, Vieira JE, Mathias LAST. Perioperative warming with a thermal gown prevents maternal temperature loss during elective cesarean section. A randomized clinical trial. Revista brasileira de anestesiologia. 2016;66:451-5.

22. Cobb B, Cho Y, Hilton G, Ting V, Carvalho B. Active warming utilizing combined IV fluid and forced-air warming decreases hypothermia and improves maternal comfort during cesarean delivery: a randomized control trial. Anesthesia \& Analgesia. 2016;122(5):1490-7.

23. Koeter M, Leijtens B, Koeter S. Effect of thermal reflective blanket placement on hypothermia in primary unilateral total hip or knee arthroplasty. Journal of perianesthesia nursing. 2013;28(6):347-52.

24. Lee WP, Wu PY, Shih WM, Lee MY, Ho LH. The effectiveness of the newly designed thermal gown on hypothermic patients after spinal 
surgery. Journal of clinical nursing. 2015;24(1920):2779-87.

25. Torossian A, Van Gerven E, Geertsen K, Horn B, Van de Velde M, Raeder J. Active perioperative patient warming using a self-warming blanket (BARRIER EasyWarm) is superior to passive thermal insulation: a multinational, multicenter, randomized trial. Journal of clinical anesthesia. 2016;34:547-54.

26. Schulz KF, Altman DG, Moher D. CONSORT 2010 statement: updated guidelines for reporting parallel group randomised trials. Trials. 2010;11(1):1-8.

27. Kim EJ, Yoon H. Preoperative factors affecting the intraoperative core body temperature in abdominal surgery under general anesthesia: an observational cohort. Clinical nurse specialist. 2014;28(5):268-76.

28. Oner N, LeCompte WA. State-trait anxiety inventory handbook: Boğaziçi University Press; 1985.

29. Palmer J, Soucier M, Deeds J. An innovative warming strategy to increase patient satisfaction. Nursing. 2019;49(7):49.

30. Kang S, Park S. Effect of the ASPAN guideline on perioperative hypothermia among patients with upper extremity surgery under general anesthesia: a randomized controlled trial. Journal of PeriAnesthesia Nursing. 2020;35(3):298-306.

31. Ozsaban A, Acaroglu R. The effect of active warming on postoperative hypothermia on body temperature and thermal comfort: a randomized controlled trial. Journal of PeriAnesthesia Nursing. 2020;35(4):423-9.

32. Conway A, Duff J, Sutherland J. Costeffectiveness of forced air warming during sedation in the cardiac catheterisation laboratory. Journal of advanced nursing. 2018;74(9):207581.

33. Kober A, Dobrovits M, Djavan B, Marberger M, Barker $R$, Bertalanffy $P$, et al. Local active warming: an effective treatment for pain, anxiety and nausea caused by renal colic. The Journal of urology. 2003;170(3):741-4.

34. Rymaszewska J, Kiejna A, Hadrys T. Depression and anxiety in coronary artery bypass grafting patients. European psychiatry. 2003;18(4):15560.

35. Park OB, Choi H. The effect of pre-warming for patients under abdominal surgery on body temperature, anxiety, pain, and thermal comfort.
Journal of Korean Academy of Nursing. 2010;40(3):317-25.

36. Kim HJ, Kim JW, Park HS, Moon DG, Lee JG, Oh MM. The use of a heating pad to reduce anxiety, pain, and distress during cystoscopy in female patients. International urogynecology journal. 2019;30(10):1705-10.

37. Tanaka N, Ohno $\mathrm{Y}$, Hori M, Utada M, Ito K, Suzuki T. High preoperative anxiety level and the risk of intraoperative hypothermia. International Journal of Clinical Medicine. 2012;3(06):461.

38. Taguchi A, Kurz A. Thermal management of the patient: where does the patient lose and/or gain temperature? Current Opinion in Anesthesiology. 2005;18(6):632-9.

39. Broback BE, Skutle GO, Dysvik E, Eskeland A. Preoperative warming with a forced-air warming blanket prevents hypothermia during surgery. Norwegian Journal of Clinical Nursing. 2018. DOI:

https://doi.org/10.4220/Sykepleienf.2018.65819

40. Connelly L, Cramer E, DeMott Q, Piperno J, Coyne B, Winfield C, et al. The optimal time and method for surgical prewarming: a comprehensive review of the literature. Journal of PeriAnesthesia Nursing. 2017;32(3):199-209.

41. Lau A, Lowlaavar N, Cooke EM, West N, German A, Morse DJ, et al. Effect of preoperative warming on intraoperative hypothermia: a randomizedcontrolled trial. Canadian Journal of Anesthesia/Journal canadien anesthesia. 2018;65(9):1029-40.

42. Thomas L, Garcia R, Desilva R, Seabra T. Intraoperative Hypothermia: Effects of Prewarming Using Forced-Air Warming in Colorectal Surgery. Journal of PeriAnesthesia Nursing. 2018;33(4).

43. Kursun $S$, Dramali $A$. The effect of heating with an electric blanket on the rewarming time in the postoperative period in patients undergoing abdominal surgery. Journal of General Medicine. 2011;21(1).

44. Benson EE, McMillan DE, Ong B. The effects of active warming on patient temperature and pain after total knee arthroplasty. AJN The American Journal of Nursing. 2012;112(5):26-33.

45. Grossman S, Bautista C, Sullivan L. Using evidence-based practice to develop a protocol for postoperative surgical intensive care unit patients. Dimensions of Critical Care Nursing. 2002;21(5):206-13. 
46. Wagner VD. Misuse of forced-air warming devices can be hazardous. Journal of Healthcare Risk Management. 2003;23(2):13-6.

47. Burns SM, Wojnakowski M, Piotrowski K, Caraffa G. Unintentional hypothermia: implications for perianesthesia nurses. Journal of PeriAnesthesia Nursing. 2009;24(3):167-76.

48. Yang HL, Lee HF, Chu TL, Su YY, Ho LH, Fan JY. The comparison of two recovery room warming methods for hypothermia patients who had undergone spinal surgery. Journal of Nursing Scholarship. 2012;44(1):2-10.

49. Balaji S, Sullivan I, Deanfield J, James I. Moderate hypothermia in the management of resistant automatic tachycardias in children. Heart. 1991;66(3):221-4.

50. Van Beek SDJ. The effect of hypothermia on physiological functions. 2013. In: Successful temperature management: A practical guide on how to prevent and treat hypothermia. The Netherlands. 2. [21].

51. Cam R, Yonem H, Ozsoy H. Core body temperature changes during surgery and nursing management. interventions. 2016;5:14. 